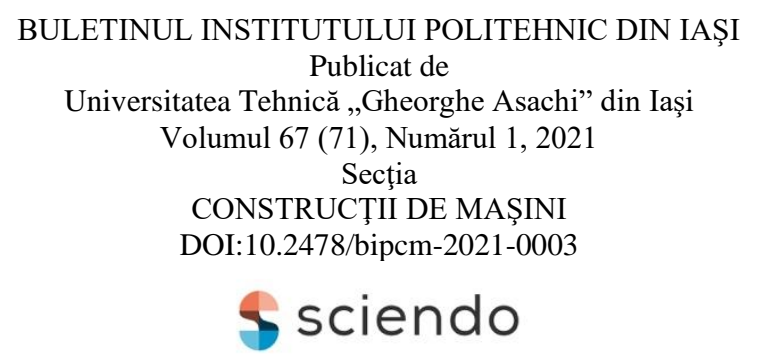

\title{
CYLINDER HEAD ANALYSIS FROM THERMAL POINT OF VIEW USING FINITE ELEMENT METHOD (FEM) OF A SPARK IGNITION ENGINE BY USING ZONAL COOLING PRINCIPLE
}

\author{
BY \\ TUDOR-MARIAN ULIAN* and ANDREI IONUȚ DONȚU \\ "Gheorghe Asachi” Technical University of Iaşi, \\ Faculty of Mechanical Engineering
}

Received: January 14, 2021

Accepted for publication: March 11, 2021

Abstract. In this paper, it is in focus a detailed analysis of the temperature distribution in the cylinder head. For this scope is build up a tree-dimensional (3D) model using Catia V5. The thermal analysis was performed using 3D finite element method, Ansys Workbench 16.1.

Keywords: cylinder head; FEM; finite element analysis; temperature distribution; engine.

\section{Introduction}

The design of modern internal combustion engines requires a precise determination of temperature distribution in order to optimize the design. Therefore, precise determination of temperature is obtained by using the finite element method with finite element analysis program, Ansys. This program, as it is known, has a great advantage that offers the possibility to use a wide range of scenarios (Ulian, 2021).

${ }^{*}$ Corresponding author; e-mail: tudor-marian.ulian@academic.tuiasi.ro (C) 2021 Tudor-Marian Ulian et al.

This is an open access article licensed under the Creative Commons Attribution-NonCommercialNoDerivatives 4.0 International License (CC BY-NC-ND 4.0). 


\section{The Analysis of the Temperature Variation of the Inside Intake Channel Depending on the Coolant Temperature}

The analysis is made on a cylinder head, shown in Fig. 1, that is created using Catia V5 and are made of cast aluminum alloy, AlSi7Cu0.5Mg.

The next step after the $3 \mathrm{~d}$ model is completed, is to import the geometry into finite element analysis software, Ansys (Kummitha, 2017; Vijayashree, 2018).

After the $3 \mathrm{~d}$ model is imported into Ansys, we need to define the material properties, temperature for the fresh air fuel mixture and temperature for combustion chamber gas. According to existing data, the conductivity coefficient for this alloy, is $\lambda_{c h}=\lambda_{A l}=122 \mathrm{~W} / \mathrm{m} 2 \mathrm{~K}$, the temperature of the fresh air fuel mixture, $T_{0}$ is considered $T_{0}=293 \mathrm{~K}$ and temperature for combustion chamber gas, $T_{g}$ is considered $T_{g}=1600 \mathrm{~K}$.

In order to run the simulation, the $3 \mathrm{~d}$ model of cylinder head is meshed by automatic mesh tool. Discretization was done with tetrahedral finite elements, having the size of $2 \mathrm{~mm}$.
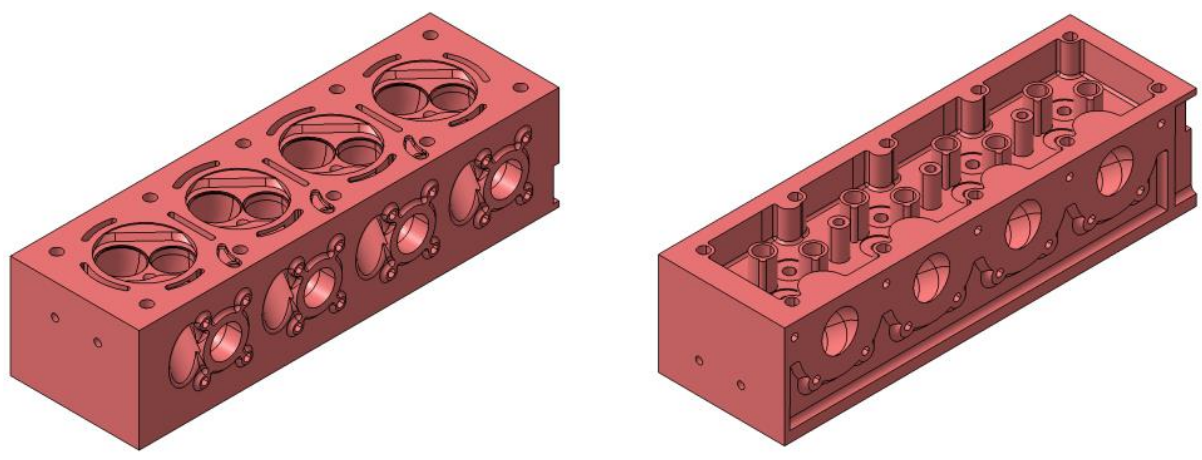

Fig. 1 - Cylinder head block (Ulian, 2021).

The previous research shows that the fresh air-fuel mixture meets with the warm engine components and it is mixed with the residual gases from the combustion chamber. These processes lead to increasing the initial temperature of the fresh air-fuel mixture and to a drastic reduction of the volumetric efficiency (Ulian et al., 2018).

The simulation gives us the possibility to study the variation of the temperature of the intake channel, $T_{p c a d m}$, depending on the coolant temperature, $T_{l r}$.

The results for this analysis shown in Fig. 2, give us information about the temperature variation of the intake channel when the coolant temperature, are $T_{l r}=50^{\circ} \mathrm{C}$ (Fig. $2 a$ ) and $T_{l r}=90^{\circ} \mathrm{C}$ (Fig. $2 b$ ). 


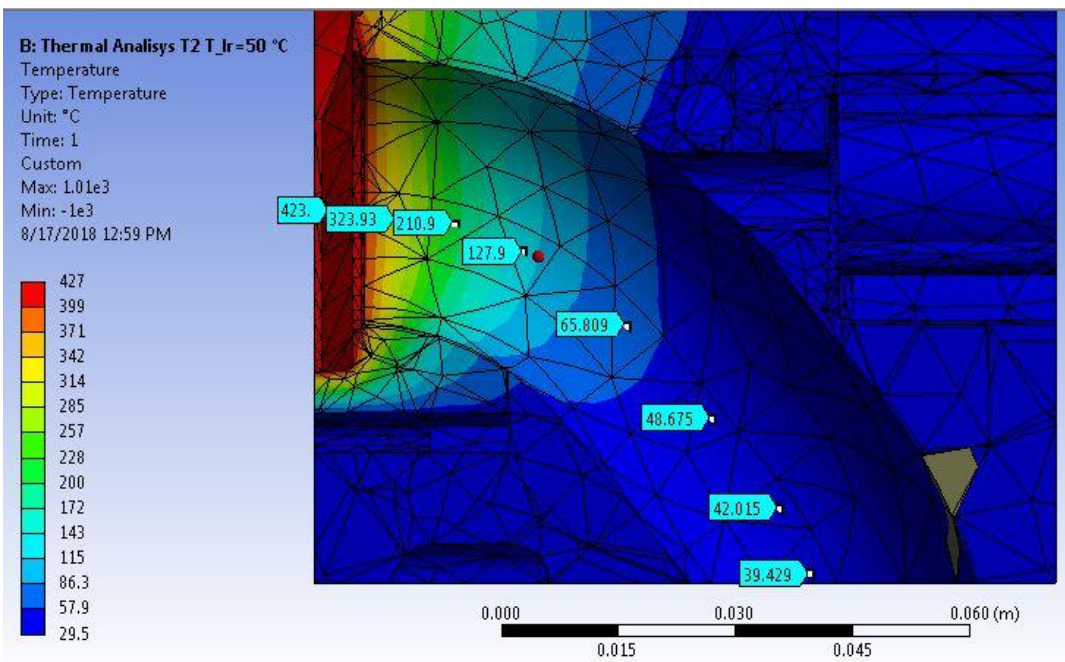

$a$

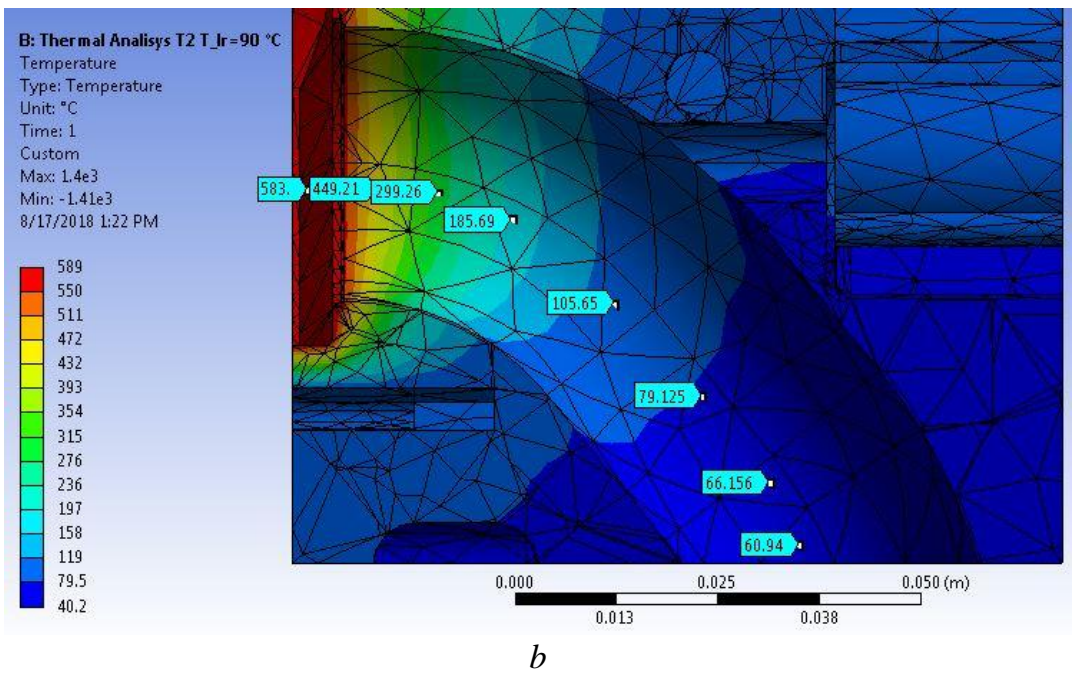

Fig. 2 - The variation of the temperature of intake channel, $T_{p c a d m}$, depending on the coolant temperature, $T_{l r}$ (Ulian, 2021).

In Fig. 3 is shown an overview regarding the temperature variation of the intake channel depending on the coolant liquid. Therefore, if it is decreased the coolant temperature from cylinder head from $90^{\circ} \mathrm{C}$ to $50^{\circ} \mathrm{C}$ the temperature of intake channel will be decreased with approximately $30 \%$. This lower cylinder head temperature will increase the volumetric efficiency and it also conduct to increased performance (Ulian, 2021). 


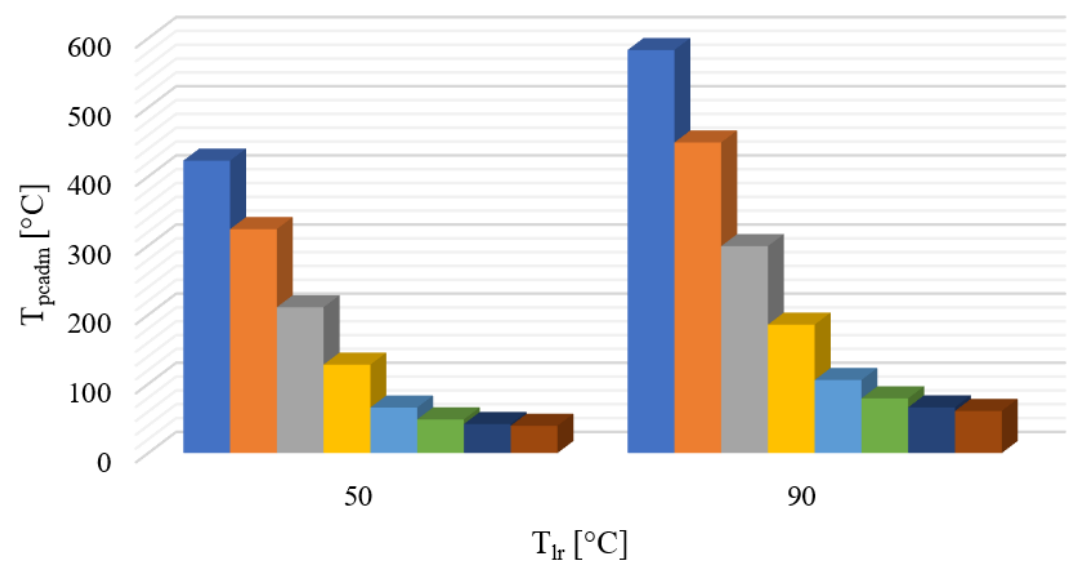

घode $1 \quad$ Node $2 \backsim$ Node $3 \quad$ Node $4 \quad$ Node $5 \quad$ Node $6 \quad$ Node $7 \quad$ Node 8

Fig. 3 - Temperature of intake channel, $T_{\text {pcadm }}$, depending on the coolant temperature, $T_{l r}$, in different nodes.

On the other hand, was also considered useful a graphical representation of an average value of the wall temperature of the intake channel, $T_{p c a d m}$, depending on the temperature of the coolant liquid, $T_{l r}$. This was also determined by FEA simulation and can be seen in the graph in Fig. 4 (Ulian, 2021).

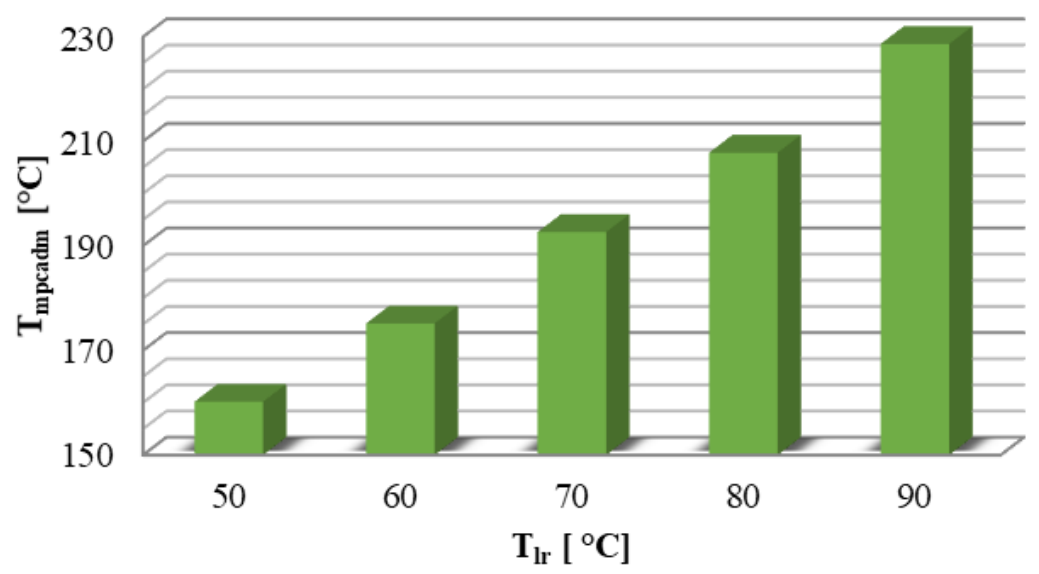

Fig. 4 - The average value of the inlet channel wall temperature, $T_{\text {pcadm }}$, as a function of the coolant temperature, $T_{l r}$, determined by FEA simulation. 


\section{Conclusions}

The results obtained in this paper, indicate that can lead to a considerable improvement in the performance and economy of the spark ignition engine by using a zonal thermal regime.

The objective of this study is to provide information for the temperature variation of the intake channel depending on the coolant liquid in order to improve the value for volumetric efficiency.

\section{REFERENCES}

Kummitha O.R., Thermal Analysis of Cylinder Block with Fins for Different Materials Using ANSYS, International Conference on Advancements in Aeromechanical Materials for Manufacturing (ICAAMM-2016), 4, 8, 2017.

Ulian T., Vornicu V., Rakosi E, Talif S., Analysis and Theoretical Modeling of Thermal Influences on the Inlet Process for a Spark-Ignition Engine, The 11th International Conference Interdisciplinarity in Engineering INTER-ENG 2017, 5-6 October 2017, Tîrgu-Mureş, Romania, 22, Elsevier, ISSN 2351 - 9789, 683-690, Inter-ENG, Tîrgu-Mureș, 2018.

Ulian T., Contribuții la ameliorarea performanțelor motorului cu aprindere prin scânteie prin utilizarea unui regim termic zonal, Teză de Doctorat, Universitatea Tehnică "Gheorghe Asachi", Iași, 2021.

Vijayashree V.G., Application of CFD for Analysis and Design of IC Engines, Advances in Internal Combustion Engine Research, Springer Singapore, 2018.

\section{ANALIZA TERMICĂ A CHIULASEI \\ MOTORULUI CU REGIM TERMIC ZONAL UTILIZÂND \\ METODA ELEMENTULUI FINIT (FEM)}

(Rezumat)

În această lucrare, este realizată o analiză detaliată a distribuției de temperaturi în masa chiulasei. Pentru această analiză s-a realizat un model tri-dimensional (3D) folosind programul de proiectare Catia V5. Analiza termică s-a realizat folosind programul de analiză ce utilizează metoda elementelor finite, Ansys Workbench 16.1. 